\title{
Religious and cultural uses of plants promoting agroecological transitions in rural settlements in Brazil.
}

\section{Usos religiosos e culturais de plantas promovem transições agroecológicas em assentamentos rurais no Brasil}

Emmanuélly Maria de Souza Fernandes ${ }^{1}$, Élvio Aparecido Motta ${ }^{2}$, Adriana Cavalieri Sais ${ }^{3}$, Renata Evangelista de Oliveira ${ }^{4}$, Renata Sebastiani ${ }^{5}$

DOI: https://doi.org/10.52719/bjas.v2i2.3789

\begin{abstract}
Nature is a sacred space, where the tradition and rituals of Afro-Brazilian religions are celebrated, which performance is essential for the conservation of natural resources. Traditional communities that practice Candomble in Brazil are settled on Nature, so they value and maintain biodiversity. Our objective was to study the spatial evolution of the land use by the traditional African-based community that occupies the Sítio Quilombo Anastácia, as well as to understand how their customs - related to the maintenance of health and food -and their rituals help in the conservation of agrobiodiversity. The monitoring of the evolution of land use was carried out using LANDSAT satellite images and images from Google Earth software. According to the timeline (elaborated for 1997-2019), there was substantial increase in vegetation cover. In addition, the planting of native trees, food and medicinal species, as well as the use of agroecological practices (such as implementation of agroforestry systems), promoted higher diversification in land use and a more sustainable use of the property. The Sítio Quilombo area favors the maintenance of the people's health and dietary habits, and the culture of this traditional African-based community guided the occupation of the soil, in order to benefit the conservation of agrobiodiversity.
\end{abstract}

Keywords: Afro descendant religion. Brazilian candomblé. Family farming. Vegetation cover. Landscape evolution. Agrobiodiversity.

\section{RESUMO}

\footnotetext{
${ }^{1}$ Universidade Federal de São Carlos - UFSCar

${ }^{2}$ Fetraf Brasil / CUT

${ }^{3} \mathrm{FAF} / \mathrm{CUT}$-SP

${ }^{4}$ Universidade Federal de São Carlos - UFSCar

${ }^{5}$ Universidade Federal de São Carlos - UFSCar
} 

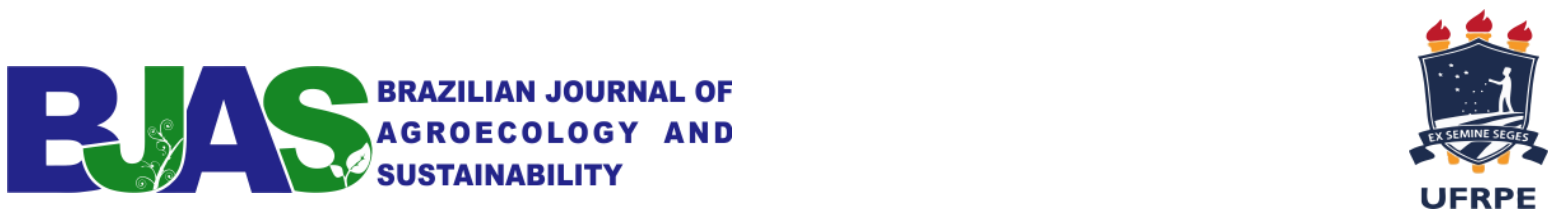

A natureza é um espaço sagrado, onde são celebradas a tradição e os rituais das religiões afro-brasileiras, cuja atuação é essencial para a conservação dos recursos naturais. As comunidades tradicionais que praticam Candomblé no Brasil estão assentadas na natureza, para que valorizem e mantenham a biodiversidade. Nosso objetivo foi estudar a evolução espacial do uso da terra pela comunidade tradicional de base africana que ocupa o Sítio Quilombo Anastácia, bem como entender como seus costumes - relacionados à manutenção da saúde e alimentação - e seus rituais ajudam na conservação da agrobiodiversidade. O monitoramento da evolução do uso da terra foi realizado com imagens de satélite LANDSAT e imagens do software Google Earth. De acordo com o cronograma (elaborado para 1997-2019), houve um aumento substancial na cobertura vegetal. Além disso, o plantio de árvores nativas, alimentos e espécies medicinais, bem como o uso de práticas agroecológicas (como a implantação de sistemas agroflorestais), promoveram maior diversificação no uso da terra e um uso mais sustentável da propriedade. A área do Sítio Quilombo favorece a manutenção dos hábitos alimentares e de saúde das pessoas, e a cultura dessa comunidade tradicional de base africana orientou a ocupação do solo, a fim de beneficiar a conservação da agrobiodiversidade.

Palavras-chave: Religiões afrodescendentes. Candomblé brasileiro. Agricultura familiar. Cobertura vegetal. Evolução da paisagem. Agrobiodiversidade.

\section{INTRODUCTION}

Landscapes are shaped by society, as a result of processes that link human and natural histories, recording material and symbolic actions of the communities that occupied them over time (Diegues, 2000; Eichemberg \& Amorozo, 2013). Several interactions are established between social and ecological processes in landscapes occupied by agriculture, and there are many challenges, considering food production in a fair and equitable way, food security, conservation of agrobiodiversity and the obtaining of social and cultural benefits. A possible alternative is to build landscapes that allow multiple objectives to coexist, such as nature conservation and the use of resources (Ros-Cuéllar, Porter-Bolland \& Bonilla-Moheno, 2019), increasing ecological functionality while bringing benefits to human well-being (Bowman et al., 2017). This new perspective involves dialoguing with local communities, promoting social participation and valorization of local and traditional knowledge, besides the development of agroecological practices (Oliveira \& Morais, 2019).

The understanding of human populations, as well as their influence on the current design of agroecosystems and landscapes (choice, arrangement, and distribution of species in different spaces), reflect their values, their history, their lifestyle and their culture. Its actions have direct 

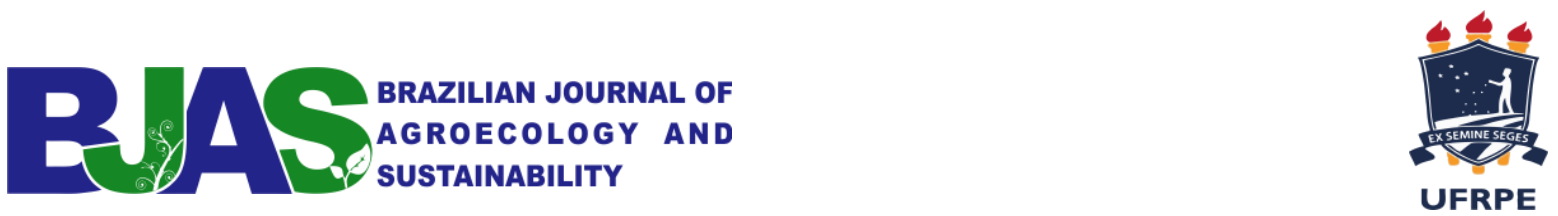

effects, positive or not, on the environment, natural ecosystems, species and their dynamics. In this context, both traditional knowledge and religious beliefs and practices can have great influence. The adoption of actions that protect local diversity and identity is an important way of facing the globalized cultural consumption market - which brings with it the risks of homogenizing and standardizing symbolic universes and identity codes (Alves, 2010).

Biodiversity has a social bias, because of numerous community practices of domestication and use in different contexts. Thus, the protection of traditional cultures in their natural environment provides an opportunity to achieve the dual objective of protecting biodiversity while preserving cultural diversity (Primack \& Rodrigues, 2001).

Traditional societies can be characterized by their dependence and even symbiosis with nature and it is believed that their culture and knowledge can collaborate with maintaining the biodiversity of ecosystems. These peoples subsist mainly on small-scale economic activities, in areas of agriculture, collecting and handicrafts (Diegues, 2000, 2004). The agrobiodiversity these populations manage requires a complex system and a deep understanding of relationships between the beings that make up the ecosystem (Nodari \& Guerra, 2015).

In many cases, communities protect the natural resources around them, an imposition usually made by older members and based on religious and traditional beliefs (Primack \& Rodrigues, 2001). Several traditional communities relate divine aspects to the elements of nature, elevating their relationship with the territorial space, especially with nature as divine and of extreme importance (Moraes, Campos, Muller, F. Gamba \& M. Gamba, 2017). Traditional African-based communities played an important role in shaping Brazilian culture, remaining faithful to the customs of their ancestors (Gomes \& Bandeira, 2012; Liporacci, Hanazaki, Ritter \& Araújo, 2017). Among these practices there is the use and manipulation of plant resources, for multiple uses, with emphasis on plants for medicinal use and for religious rituals (Sales, Albuquerque \& Cavalcanti, 2009).

Strategies that value intangible heritage - as present in Afro-descendant religions (Baldiotti \& Santana, 2020), combined with those that promote resilience and food security (Food and Agriculture Organization of the United Nations [FAO], 2019), can be a way to build a new pattern of development in rural areas, which balances productive, social, cultural and religious aspects, and values local lifestyle. In Brazil, afro-descendant religions can also be called "nature based religions" since they occupy a central role in their traditions (Santos \& Gonçalves, 2011). In them there is a strong need for the terreiros, spaces destined to cults, to be surrounded by the natural environment, inseparable constituent of this universe, which 

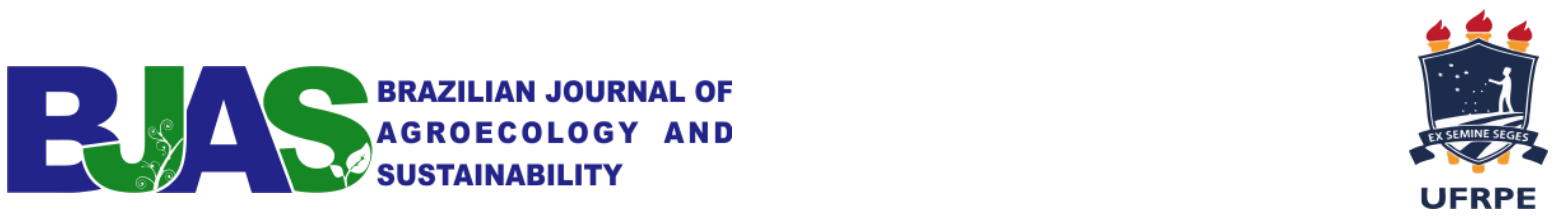

integrates their rites and the identity of their gods, motivating feelings of respect, servitude and belonging (Boaes \& Oliveira, 2011).

According to Santos (1998), Afro-Brazilian religions, despite their variations, which are many, retain concepts and practices that refer to nature and its elements, the intimacy of the sacred beings in which they believe. Knowledge of vegetables is important for many rituals, particularly in the organization of religious cooking and healing activities. For the author:

\begin{abstract}
"Afro-Brazilian religions have been transformed by changes in society and have prospered in attendance of the beliefs and afflictions of the urban world (...). The urban world and the cultural legacies of which they are a fruit have marked, in these religious traditions and practices, the ways in which vegetation and vegetables are used and understood. It is a plural vegetation in terms of origins; it concerns now native, African or other species; that were and are democratically represented in the repertoire of plants used. A variety of trees appear in association with divinities of Afro-Brazilian religions, in a generic way or in specific centers of specific cults (...) the trees are like altars of nature. (...) It is important to note that through religious conceptions, species are domesticated and the symbolic forest they form does not necessarily correspond to a real forest (...), however, groves and forests that still exist are used to some of their practices, and have them as places of energy and spiritual communication." (Santos, 1998, p. 128)
\end{abstract}

Borba (2018) also highlights the importance of these religious traditions for conservation.

For the author:

“Traditionally, African religions have always been ritually linked to nature (...). His religious tradition adds important contributions to society, especially with regard to the use and preservation of forests, opposing the philosophy of domination propagated by Western society, in which man subdues nature only to use it." (Borba, 2018, p. 4).

These traditions, in addition to assisting in the conservation of natural forest remnants, also contribute to the conservation of plant diversity associated with their practices. According to Borba (2018), no Candomblé ritual is performed without the presence of leaves, which hold the axé (power) essential for their divinities. For the author "it is with time and observance of the practice of ancestors that one learns to properly manipulate leaves and, mainly, one learns to preserve them" (Borba 2018, p. 4).

Candomblé is a culture created in Brazil and brings together knowledge, world views and of relating to different peoples brought from Africa from the 16th century onwards, with the greatest representatives of the Banto, Nagô and Jeje ethnic groups (Gomberg, 2011), which can be associated with traditional African-based communities. In its initiation process, several procedures are carried out continuously, following traditional knowledge and guidelines established through oracular consultation. This is also how each person's Orixá is revealed, under the guidance of the leaders of the terreiro. Knowing the link with your Orixá allows you to know a whole context of corporal conscience of the energetic link between body and nature, 

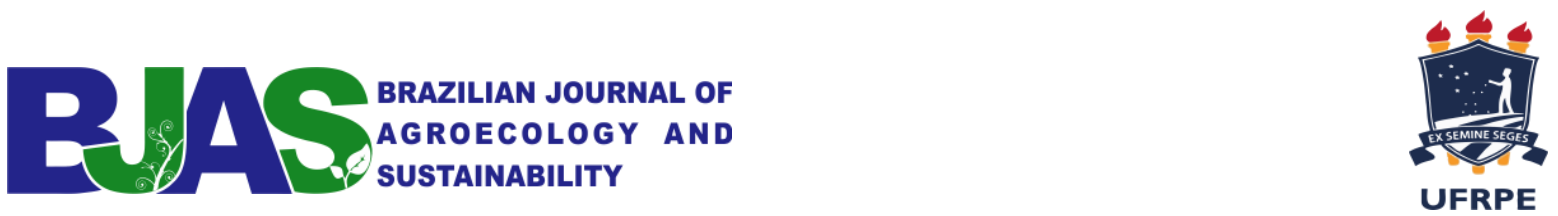

as well as knowing some predispositions to diseases and the development of skills. This conception is based on a vision of health as an energy balance (Gomberg, 2011).

\footnotetext{
"The social construction of the individual, of the person, within the scope of the terreiros is gradually developed from, as already said, an initiation process. The initiation and experience in the terreiro are responsible for the slow and gradual establishment of a world view and a way of being peculiar to a belief system that privileges the human body and health. "(Gomberg, 2011, pg. 64)
}

Alchorne and Cunha (2017) discuss the issue of cultural insertion through capitalist development and modernity. Cultures are dynamic, especially when there are cross-cultural relationships, fostering exchanges that lead to acquisitions, losses and cultural innovations. And with this view it is possible to see how the people of the terreiro knew how to reinvent their cults to continue with religious habits and practices. These people are based on nature, having as a pillar the connection with natural elements seen as a manifestation of the ancestors. For the maintenance of their habits and rituals they depend on clean water and on several species of plants, being impossible to distinguish between subject and nature as immanent dimension of life (Alchorne \& Cunha, 2017).

When considering the close relationship between the people who make up traditional African communities and nature, it is expected that these communities, especially when in rural areas, will dedicate themselves not only to planting for their use in religious rituals, as is the case of Candomblé, but also for the health and food security of its members. In this case, it is possible to recognize the development of family farming in these communities.

Considering the importance of a quilombo (Sítio Quilombo Anastácia, municipality of Araras, São Paulo State, Brazil) for the maintenance of its cultural practices, such as religious rituals and taking into account the intimate connection of this community with nature, there is in progress a research to understand the relationship between the spatial arrangement of the species cultivated and used in this area, and the socio-cultural characteristics of these people, based on their experience with the community who lives there. We understand that the cultural tradition maintained by the members of this community influences directly the forms of land use and occupation, benefiting the conservation of agrobiodiversity, since they develop their religious practices, as well as customs related to the maintenance of health and food, closely linked to the nature. So, the present study (part of this broad research) aimed to follow the spatial evolution of land use by the traditional African-based community that occupies the Sítio Quilombo Anastácia. 


\title{
2 METHODOLOGY
}

\subsection{Characterization of the study area}

\section{The sítio quilombo anastácia}

\begin{abstract}
Cosi euê / Cosi orixá / Euê ô / Euê ô orixá / Leafless has no dream / Leafless has no life / Leafless has nothing / Who are you and what you do around here / I keep the starlight / The soul of each leaf / I am aroni / I keep the starlight / The soul of each leaf / I am aroni / Cosi euê / Cosi orixá / Euê ô / Euê ô orixá / No leaf has no dream / No leaf has no party / No leaf has no life / No leaf has nothing / I keep the light of the stars / The soul of each leaf / I am aroni. ("Save the Leaves", by the poet Mário de Andrade)
\end{abstract}

The struggle for agrarian reform in Brazil is not recent and is due to the growing social organization of social movements in the countryside (Carvalho, 2017). In a country marked by land concentration, this struggle reveals the complexity and contradiction of the development process of capitalist forces in Brazilian agriculture and the occupation of land as a strategy of social movements reveals that agricultural productivity does not include improving the lives of Brazilian farm workers (Carvalho, 2017). Farmers' families are characterized by the accumulation of knowledge and knowledge developed and appropriated for generations, constituting a heterogeneous, diverse, and complex portion of the group of Brazilian workers (Santos, 2017). This aspect also applies to traditional African-based communities, in which the accumulation of knowledge linked to survival and religiosity is mixed.

The Sítio Quilombo Anastácia (SQA) is in the Araras III Settlement, founded in 1997 in the municipality of Araras (SP, Brazil). The space is a territory acquired from a process of struggle for land that took place in July 1995, with an area of 5.8 hectares, home to a traditional African-based community led by the priestess Doné Oyacy (Rosa Maria Virgulino da Silva) and the priest Tata Kejessy (Elvio Aparecido Motta). The Traditional Community of Terreiro Ylê Axé de Yansã, belonging to the nation Jeje Nagô and constitutes the Civil Society Organization of Public Interest Ylê Axé de Yansã, established in the statutes on September 15, 1994. It was recognized and declared of municipal public utility on December 3, 2002 (municipal law $n^{\circ} 3,475$ ) and in December 2018 it was recognized by the Ministry of Culture through the Secretariat of Cultural Diversity as a Point of Culture (federal law $n^{\circ} 13.018 / 2014$ ) in the Cultura Viva (Alive culture) Program of the State of São Paulo.

SQA has its daily life based on the collectivity and constitutes a space of resistance for black culture, for the spirituality of the African-based and for religious, educational, and sociocultural events. The matriarchal organization community maintains and values the traditions of African origin, in the different areas that constitute it and is a space of coexistence, of prominence and reference in the Araras III Rural Settlement. Since 1996, it has been developing training activities in social technologies for diverse audiences, which reproduce their learning 

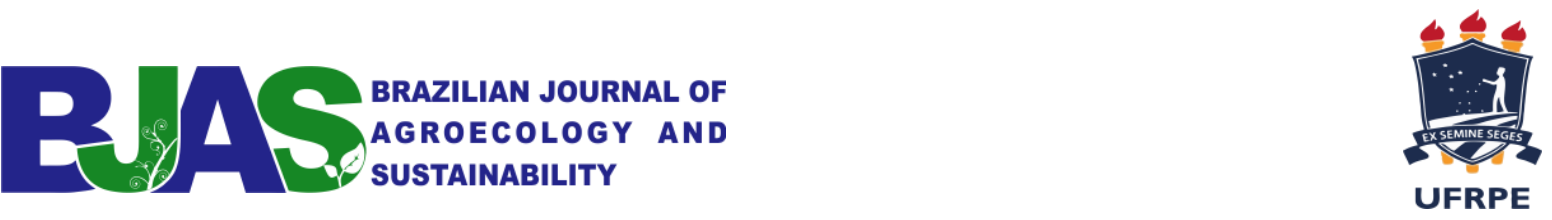

in other spaces, culminating in the constitution of social networks that promote economic, regional development, and living conditions in both rural and urban environments.

SQA receives young people and adults of different ethnicities and members of social movements for courses, experiences, socio-political and cultural backgrounds. It is the headquarters of TEFOKAFUMI, which is the tent of Kafú Milodè Training and Citizenship in its tenth edition in 2020, has already received in 2019 the ENJUFE (Youth Meeting of FECONEZU, Black Zumbi Community Festival) and in 2018 the State Meeting of University Students Negros e Negras in a partnership with UEE (Union of Students of the State of São Paulo). Among the training activities offered by the space, there are ancestral knowledge workshops (gastronomy workshops, medicinal herbs and home remedies); Valuation, rescue and cultural and identity maintenance (religious and ethnic clothing sewing workshops, aesthetics (braid and makeup), sexuality, self-recognition lectures, capoeira, percussion, construction of instruments and afro dance); Conscious management of the Territory (planting of agro-ecological and organic foods, agroforestry systems and bioconstruction); and aquilombamentos (formations, meetings, meetings of the regional black movement, residences, lectures, seminars, visits and educational activities).

The cultivation of the land is based on the maintenance of its religiosity, health, and food, through family farming practices. African ancestry in their continent of origin and in the diaspora is explained by the connection with the land, more specifically with nature. The sacred aspect of the land is complemented and materialized in Brazil first by the historical process of denying the right to access, and secondly by being the food for everything that is necessary for our survival (land, life that generates other lives). It is from this reading that we can understand the option of the SQA's leaders to join in the struggle to access land. The land for traditional families linked to religions of African origin is the place where the sacred is based. The place where the myths related to cults to orixás, inquices and voduns are explained, is ayé (Earth, which here has a double connotation, as a totalizing space and, therefore, sacred, but also, and for this very reason, linked to nature).

The itans (myths and tales) that base and structure the functioning of these cults connect men and women from ayé to orun (spiritual world), through access to land, because it is in this space, in the midst of the elements that make up nature that, ritualistically, there are the divinities that are worshiped in the Candomble liturgy.

Popularly, as Mário de Andrade indicates in the poem "Save the Leaves", without a leaf he has no dream, party, life and, therefore, nothing, since the leaves are part of the enchantments 

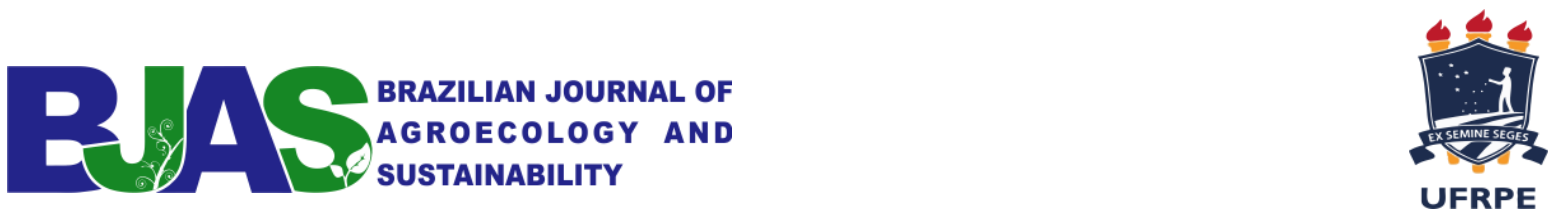

that structure the Candomble liturgy. Therefore, Nature is, through ancestry and history, the living space and, therefore, cult of the sacred.

\section{Spatial evolution land use}

The systematization of the data was made according to Jara-Holiday (2006) and aimed to describe the experience of Sítio Quilombo Anastácia, regarding the management and cultivation of medicinal, nutritional, and useful plants used in their daily lives - which reflect the social and cultural reproduction of the "day-to-day life" of the farm, guided by the knowledge of its ancestors, passed from generation to generation. For that, individual interviews and periodic meetings were carried out and the strategy of this action was to establish a chronology in order to recognize the different uses of the land over the analyzed period and which factors influenced this process. The non-resident authors registered the information, LANDSAT images and visits, it is worth mentioning that the author residing in the study area was present since the beginning of the site implantation and directly interfered in all stages of this study.

Landsat satellite images obtained in 1997 (when the Araras III Settlement was created) and Google Earth images from 2004, 2010 and 2019. In parallel, visits were made to recognize the areas defined for different uses. The evolution of land use in the SQA was mapped by satellite images with the assistance of the resident author of Sítio Quilombo Anastácia. The present study was approved and authorized by the Research Ethics Committee of Universidade Federal de São Carlos (CAAE 38149520.6.0000.5504).

\section{RESULTS AND DISCUSSION}

From the monitoring of the timeline (1997-2019), it was possible to observe a substantial increase in the vegetation cover around the family residence (Table 1), as well as diversification within the lot system, mainly increased by food, medicinal and religious plants, such as Artocarpus heterophyllus Lam., Genipa americana L., Mangifera indica L., Psidium guajava L., Pachira aquatica Aubl., Anacardium occidentale L., Plinia cauliflora (Mart.) Kausel., Malpighia emarginata DC., Ruta graveolens L., Aloe vera (L.) Burm.f., Psidium cattleianum Afzel. ex Sabine, Bactris gasipaes Kunth. and Elaeis guineensis Jacq. This vegetation contains some tree species native to the region, such as Dalbergia spruceana Benth., Casearia sylvestris Sw., Piptadenia gonoacantha (Mart.) J.F.Macbr and Miconia serrulata (DC.) Naudin. There are also exotic and native species, grown throughout the family's stay at the area, such as 
Sansevieria trifasciata Prain, Euphorbia tirucalli L., Kalanchoe Adans. spp., Amaranthus L. sp. and Costus L. sp.

Chart 1: Temporal and spatial evolution of land use at Sítio Quilombo Anastácia (Araras, São Paulo State, Brazil)

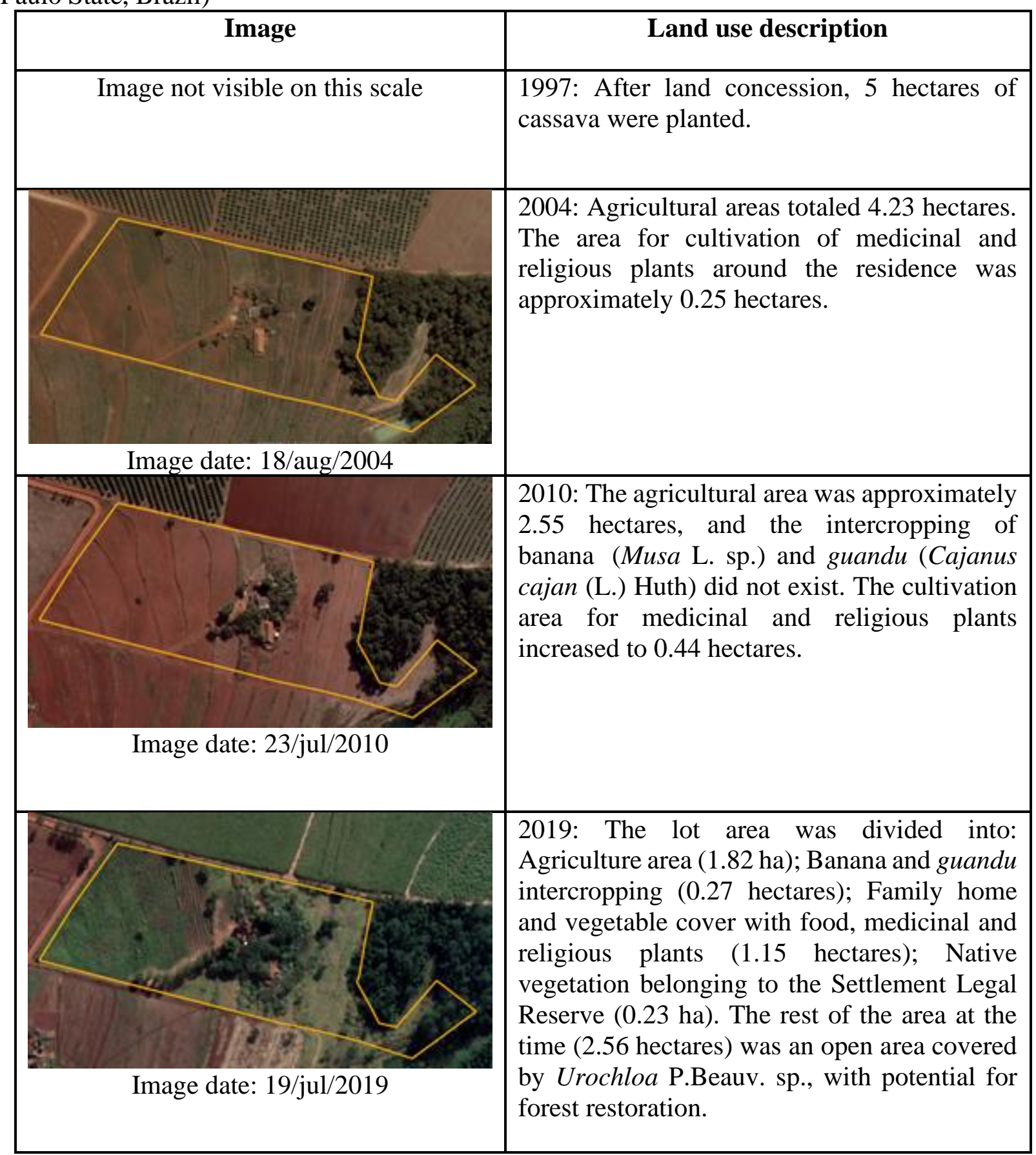

Source: Historical images from Google Earth.

Any actions that introduce greater diversity in agroecosystems and rural landscapes help to mitigate negative impacts of agrarian activities, and reduce risks for farmers, involved in a constantly changing reality (Altieri, Nicholls, Henao \& Lana, 2015; Gliessman, 2009). In addition, systems with a greater variety of species contribute to the conservation of 

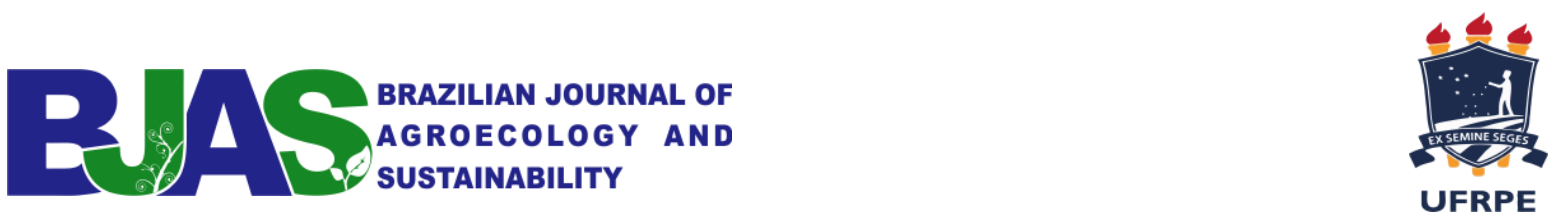

agrobiodiversity in agricultural spaces (Eichemberg \& Amorozo, 2013), which is confirmed by the results found in this research. In this sense, agroforestry systems - for having multiple possibilities for intercropping models - can be an interesting strategy and bring diversity and generate resilience for the populations that cultivate them.

The intercropping of guandu (Cajanus cajan (L.) Huth) and banana (Musa L. sp.) (see Table 1) is an agroforestry system, that improve the family feeding and generate income to the property, through the commercialization of surplus production at family farmers' fairs organized in Araras county. The sustainable use of natural resources associated with systems with less independence from external inputs results in greater food security (Franco, 2017). Here, in the context of food security, self-consumption for family farming is inserted, which allocates part of the products for consumption by the family, with the surplus exchanged or sold, in order to complement and guarantee improvement and greater availability of food (Santos, 2017).

The area belonging to the Legal Reserve did not change during the period of analysis, but there is a restoration project in the initial phase for the Settlement, which includes SQA areas (the intention is to plant native species for the use of an apiary with of Jataí bees (Tetragonisca angustula (Latreille, 1811)). SQA water tank is part of the water supply system for the settlement. Understanding, recognizing, and valuing collective arrangements related to the use and conservation of water in rural areas can guide social mobilization to face problems and overcome challenges related to water resources (Chiodi, 2017). The fact that SQA is part of an ecological restoration project reinforces the importance of traditional communities and family farmers in the conservation of biodiversity, since in their traditional management systems restoration and production for subsistence is the same thing (Rodrigues, 2013).

According to Silva (2019), the challenges of testifying the residents belonging to a community in certain territories, as well as the ecological vocation of their livelihoods, comes from a colonial heritage. However, the conduct they adopt in their territories tends to force the governments to recognize the existence of different tenure regimes, which strengthens the struggle for the recognition of these cultural practices, compatible with conservation.

In general, family farmers are responsible for maintaining more complex and diversified farming systems (Altieri, 2002; Altieri, et al., 2015) that may, in the future, be the key to the establishment of new, more sustainable, and innovative forms of production. Family farming suggests a diversity of situations in which farmers' adaptability determines their way of life and social relationships, influenced by economic and environmental resources, and inserted in each social, cultural and political context (Santos, 2017). The adaptability and resilience of SQA 

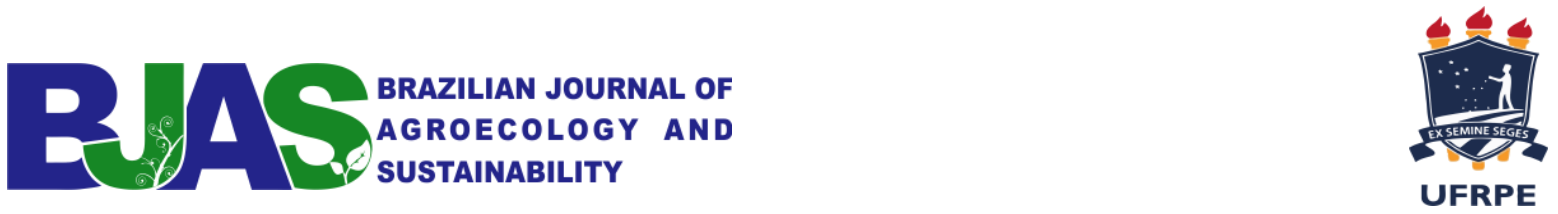

residents can be observed in their "planning for the future". Figure 1 presents a sketch with the planning of diversifying activities adopting agroecological principles.

Figure 1: Sketch showing SQA restructuring, planned by the local in 2019.

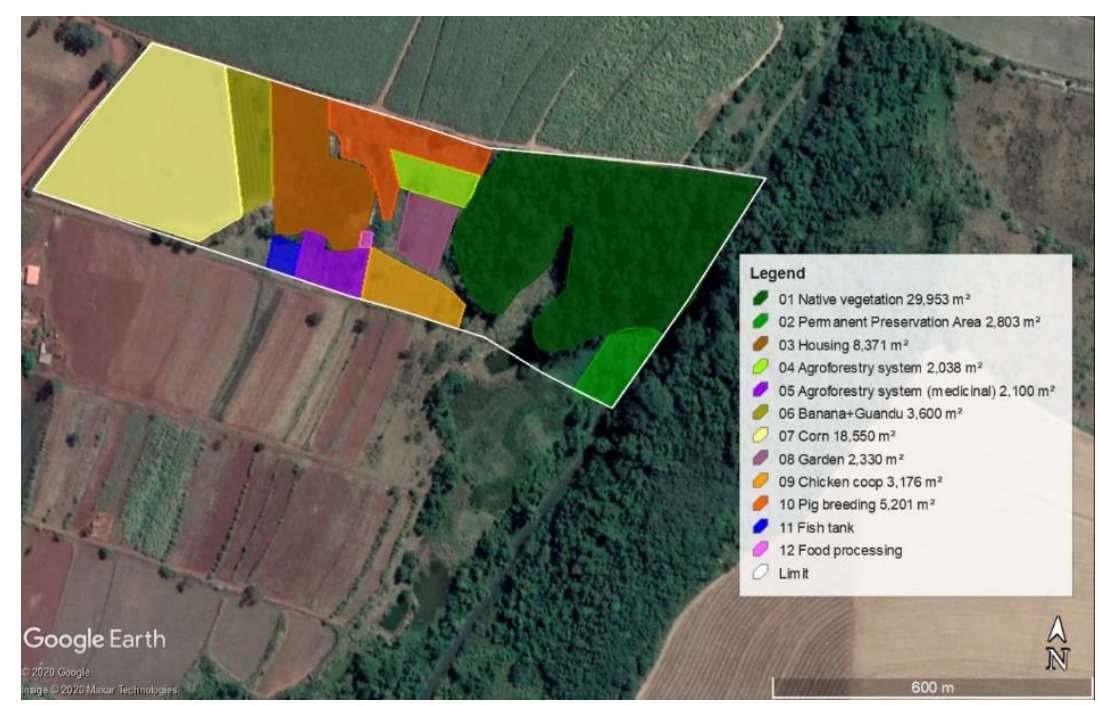

Source: Élvio Aparecido Motta.

According to Silva (2019), it is possible to associate environmental conservation and the ways of life of traditional communities. These communities, which were previously seen as barriers to both development and conservation of biodiversity, now have legal instruments to defend their rights and have contributed greatly to both aspects.

\section{FINAL CONSIDERATIONS}

Sítio Quilombo Anastácia residents are managing the spatial evolution of its space, favoring the maintenance of its religious culture, health, and food. The culture of this traditional African-based community guided the process of land occupation to improve vegetation cover, diversify the land use and favor the use and the conservation of agrobiodiversity.

\section{REFERENCES}

Alchorne, M. A.; Cunha, A. P. (2017). Agroecologia e Povos de Terreiro. In: FIGUEIRO, M. A. B.; MATTOS, J. L. S.; FONCESA, F. D. (Org.). Agroecologia e diálogo de conhecimentos: Olhares de povos e comunidades tradicionais, movimentos sociais $e$ academia (pp 47-60). Recife: UFRPE.

Altieri, M. A. (2002). Agroecology: the science of natural resource management for poor farmers in marginal environments. Agriculture, Ecosystems and Environment, 93, 1-24. doi.org/10.1016/S0167-8809(02)00085-3 

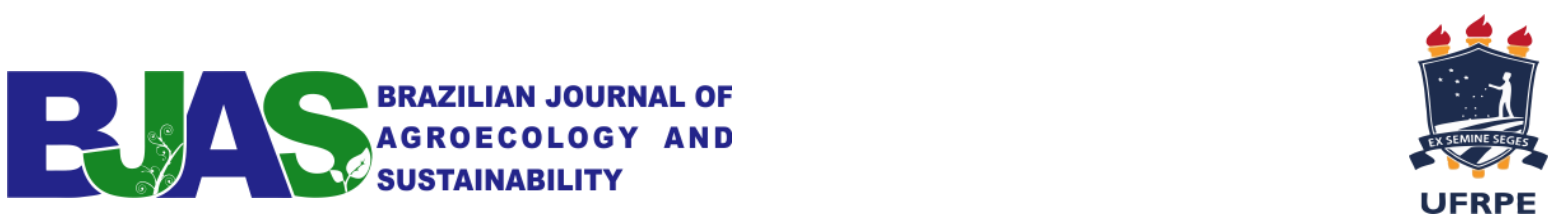

Altieri, M. A.; Nicholls, C. I.; Henao, A.; Lana, M. A. (2015). Agroecology and the design of climate change-resilient farming systems. Agronomy and Sustainable Development, 35, 869-890.

Alves, E. P. M. (2010). Diversidade Cultural, Patrimônio Cultural Material e Cultura Popular: a Unesco e a Construção de um Universalismo Global. Revista Sociedade e Estado, 25(3), 539-560.

Anacleto, D. D. A., Souza, B. D. A., Marchini, L. C., \& Moreti, A. C. D. C. C. (2009). Composição de amostras de mel de abelha Jataí (Tetragonisca angustula latreille, 1811). Food Science and Technology, 29(3), 535-541.

Baldiotti, G. R. C.; Santana, T. R. (2017). A umbanda como patrimônio cultural material e imaterial. Revista África e Africanidades, 33, 1-13.

Boaes, A. G.; Oliveira, R. S. Religiões Afro-brasileira e ética ecológica: ensaiando aproximações. (2011). Revista Brasileira De História Das Religiões, 3(9). doi.org/10.4025/rbhranpuh.v3i9.30368

Borba, D. M. (2018, agosto). Florestas: espaço sagrado das religiões de matriz africana. Anais do Encontro Estadual de História, Joinville, SC, Brasil, 17.

Carvalho, J. G. (2017). Questão agrária e a violência contra os camponeses. In: Borsatto, R.S (Org.). O papel da extensão rural no fortalecimento da agricultura familiar e da agroecologia: textos introdutórios (pp. 11-12). São Carlos: Edufscar.

Bowman, D. M. J. S; Garnett, S. T.; Barlow, S. Bekessy, S. A.; Bellairs, S. M.; Bishop, M. J.; Bradstock, R. A.; Jones, D. N; Maxwell, S. L.; Pittock, J.; Toral-Granda, M. V; Watson, J. E. M.; Wilson, J.; Zander, K. K.; Hughes, L. (2017). Renewal ecology: Conservation for the Anthropocene. Restoration Ecology, 25(5), 674-680.

Chiodi, R. E. Uso e conservação de recursos hídricos. (2017). In: Borsatto, R.S (Org.). O papel da extensão rural no fortalecimento da agricultura familiar e da agroecologia: textos introdutórios (pp. 45-46). São Carlos: Edufscar.

Diegues, A. C. (2004). O mito moderno da natureza intocada. (5 ed). São Paulo: Hucitec/ NUPAUC/CEC;

Diegues, A. C. (2011). Os saberes tradicionais e a biodiversidade no Brasil. São Paulo: MMA/COBIO/NUPAUB/USP.

Eichemberg, M. T.; Amorozo, M. C. M. (2013). Contributions of the old urban homegardens for food production and consumption in Rio Claro, Southeastern Brazil. Boletim do Museu Paraense Emilio Goeldi, Ciências Humanas 8(3), 745-755.

FAO - Food and Agriculture Organization of the United Nations. (2019) The state of the world's biodiversity for food and agriculture. J. Bélanger \& D. Pilling (Eds.). (pp. 572). FAO Commission on Genetic Resources for Food and Agriculture Assessments. Rome. Recuperado em 11 de agosto de 2019, de http://www.fao.org/state-of-biodiversity-forfood-agriculture/en/. 

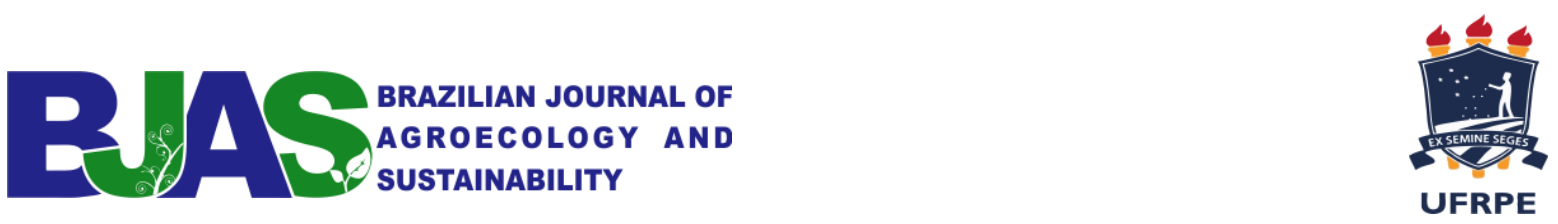

Franco, F. S. (2017). Sistemas agroflorestais para a restauração e resiliência socioambientais na agricultura familiar camponesa. In: Borsatto, R.S (Org.). O papel da extensão rural no fortalecimento da agricultura familiar e da agroecologia: textos introdutórios. (pp. 4143). São Carlos: Edufscar.

Gliessman, S. R. (2009). Agroecologia: Processos ecológicos em Agricultura Sustentável. Porto Alegre, Editora Universidade UFGRS.

Gomes, T. B., Bandeira, F. P. S. F. (2012). Uso e diversidade de plantas medicinais em uma comunidade quilombola no Raso da Catarina, Bahia. Acta Botânica Brasílica, 26, 796-809.

Gomberg, E. (2011) - Hospital de orixás: encontros terapêuticos em um terreiro de candomblé. Salvador: EDUFBA.

Jara-Holliday, O. (2006). Para sistematizar experiências. (2ª ed.) Brasília: MMA

Liporacci, H. S. N., Hanazaki, N., Ritter, M. R., Araújo, E. L. (2017). Where are the Brazilian ethnobotanical studies in the Atlantic Forest and Caatinga? Rodriguésia, 68(4), 1225-1240. doi.org/10.1590/2175-7860201768407

Moraes, R. N.; Campos, A. C.; Muller, N. M.; Gamba, F. B.; Gamba, M. F. D. D. F. (2017). As comunidades tradicionais e a discussão sobre o conceito de território. Revista Spacios, 38(12), 17-24.

Nair, P.K.R. (1993). An introduction to agroforestry. Dordrecht. Boston: Kluwer Academic Publishers/ICRAF.

Nichols, C. I.; Altieri, M. A. (2018). Pathways for the amplification of Agroecology. Agroecology and Sustainable Food Systems, 42(10), 1170-1193. doi 10.1080/21683565.2018.1499578

Nodari, R. O; Guerra, M. P. (2015). A agroecologia: estratégias de pesquisa e valores. 2015. Estudos Avançados, 29: 183-207.

Oliveira, R. E.; Moraes, L.F.D. Conservação da Biodiversidade nos Agroecossistemas. In: Stadnik, M. J.; Velho, A. C.; Zorrilla, S.C. (Eds.). Desenvolvimento sustentável na produção agroalimentar/Desarrollo sostenible en la producción agroalimentária (pp. 1934) Florianópolis: $C C A / U F S C$.

Primack, R.B.; Rodrigues, E. (2001). Biologia da conservação. Londrina: Editora Planta.

Rodrigues, E. (2013). Ecologia da Restauração. Londrina: Editora Planta.

Sales, G. P. S. Albuquerque, H. N.; Cavalcanti, M. L. F. (2009). Estudo do uso de plantas pela comunidade quilombola Senhor do Bonfim - Areia - PB. Revista de Biologia e Ciências da Terra, (1), 31-36.

Santos, J. L. (1998). Religião e Florestas. Série Técnica IPEF, 12(32), 127-132.

Santos, L. L. (2017). A inserção dos agricultores familiares na agenda de políticas públicas de segurança alimentar. In: Borsatto, R.S (Org.). O papel da extensão rural no fortalecimento 

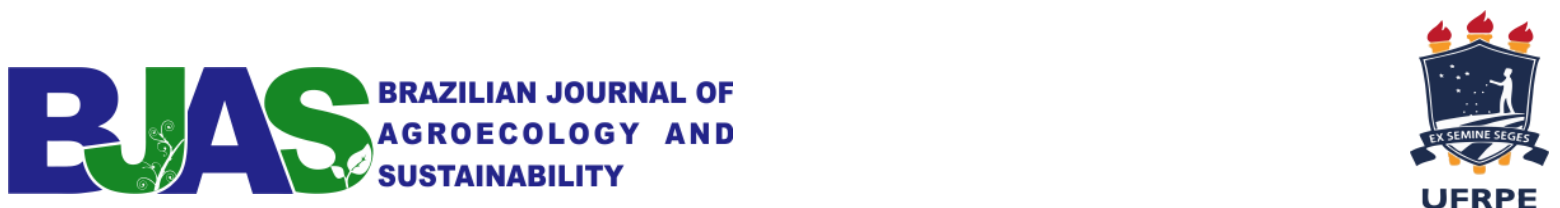

da agricultura familiar e da agroecologia: textos introdutórios (pp. 19-23). São Carlos: Edufscar.

Santos, R. O; Gonçalves, A. G. B. (2011). A Natureza e seus significados entre adeptos das religiões afro-brasileiras. Revista Brasileira de História das Religiões, 3(9).

Silva, A. T. R. Áreas protegidas, populações tradicionais da Amazônia e novos arranjos conservacionistas. (2019). Revista Brasileira de Ciências Sociais, 34(99), 1-22.

Ros-Cuéllar, J.; Porter-Bolland, L.; Bonilla-Moheno, M. (2019). Can Multifunctional Landscapes Become Effective Conservation Strategies? Challenges and Oportunities from a Mexican Case Study. Land, 8(6). doi:10.3390/land8010006

\section{AKNOWLEDGEMENTS}

The authors thank Centro de Ciências Agrárias (Universidade Federal de São Carlos), Programa de Pós-graduação em Desenvolvimento Rural and Conselho Nacional de Desenvolvimento Científico e Tecnológico (CNPq). 